DEUİFD XLVI / 2017, ss. 261-263.

\title{
STRES VE DİN
}

(Behlül Tokur; Çamlıca Yayınları- İstanbul, Ocak 2017-; 184 s.)

Abdurrahman AKBOLAT ${ }^{1}$

Din bilimlerindeki gelişmelerle birlikte ele alınan konular ve araştırmalarda kullanılan metodolojiler de bu gelişime uygun bir şekilde artmakta ve genişlemektedir. Behlül Tokur'un kaleme aldığ1 "Stres ve Din" başliklı bu eser de bu gelişimin bir ürünü olarak karşımıza çıkmaktadır. Eser, okuruna sade bir dille hitap etmektedir. Yazarın bölüm, ana ve alt başlıklarının başarılı ve yerinde bir ayırım yaptığını söylemek mümkündür. Yazarın doktora çalışmasını temel alarak yazdığ1 eser iki ana bölümden oluşmaktadır. Birinci bölüm "Stres" başlığı altında, stres kavramının tanımlamasını, stresle ilgili modelleri ve bu modellerin izahatlarını, stresin kaynaklarını ve bu kaynağın alt dallarını, stresin sonuçlarını, başa çıkma kavramını, stresle başa çıkma stratejilerini ele almaktadır. İkinci bölüm "din ve stres" başlı̆̆ı altında, din ve dindarlık kavramlarına, din- sağlık ilişkisine, din stres ilişkisine değinmektedir.

Yazar, stres kavramına değinirken stresi, asrın hastalı̆g olarak nitelemektedir. Stresin akla gelen anlamını biraz daha genissleterek ve daha bir şümullü yapıda olduğunu vurgulayarak "ağır ve zor yaşam koşuşu" şeklinde ilk defa bu eserde kullanıldığ1 yazarca açıkça belirtilmektedir. (s. 17). Tokur, stresin kavramının tarihsel serüveninden de bahsettikten sonra üç temel stres modelini (tepkiye dayalı stres modeli, etki odaklı stres modeli, arabulucu stres modeli) ele almaktadır. Stresin hayatın her alanında her zaman meydana gelebileceğini ifade eden yazar, literatüre bakıldığında stresin kaynağının genellikle şu üç faktör olduğunu ifade etmektedir: Psikolojik kaynaklar, çevresel ve sosyal faktörler, örgütsel (iş ortamı) faktörler. Stres kavramına stresin sonuçlarına değinerek devam eden yazarımız bu sonuçları fizyolojik sonuçlar, psikolojik sonuçlar ve eylemsel sonuçlar olmak üzere üç başlık altında ele almaktadir.

1 Arș. Gör., İzmir Katip Çelebi Üniversitesi İslami İlimler Fakültesi Din Bilimleri A.B.D., abdurrahman.akbolat@ikc.edu.tr 
Stres kavramını tüm detaylarıyla ele aldıktan sonra stresle başa ç1kma konusuna değinen Tokur (s. 75), öncelikle başa çıkma kavramı üzerinde yoğunlaşmaktadır. Stresle başa çıkma amaçlarını dönemlere ayırarak irdeleyen yazar, stresle başa çıkma esnasındaki davranışlara değinmektedir. Her ne kadar yazarımız stresle başa çıkma üzerine derinlemesine bir tefekküre bizleri götürse de stresin aslında yaşamin olmazsa olmazı diğer bir ifadeyle insanın bir var oluş emaresi olduğunu da vurgulamaktan geri kalmamaktadır (s.78). stresle başa çıkma stratejilerini ele alan yazar bu konuyu, zihinsel stratejiler (aşırı genelleme, hemen bir sonuca ulaşma, duygusal mantık yürütme, aşırı büyütme ya da aşır1 küçültme, öz değerlendirme), bedensel hareketler (spor ve egzersiz), gevşeme, beslenme, sosyal destek, ibadet ve dua başlikları altında sınırlandırmaya çalışmaktadır. Ülkemiz açısından bu çalışmanın en farklı noktalarından birisi, kanaatimizce, sosyal destek kavramına değinmesidir. Bir başa çıkma stratejisi olarak sosyal desteği çalışmalarında insanı merkezine alan araştırmacıların üzerinde dikkatli bir şekilde durması gereken önemli bir husustur. $\mathrm{Bu}$ düşünceyi sosyal desteğin ve sosyalleşmenin iç içe geçmiş iki olgu olduğunu yazar aç1kça vurgulamaktadır (s.90). Yazarımız her firsatta çalışmasını ansiklopedik bilgilerle boğmaktan kaçınmak adına sadece üslubunu değil aynı zamanda örneklerini de kendine has bir biçimde okuyucusuna sunmaktadır. Bölüm sonunda "bir hikâye" başlı̆̆1 altında okuyucuya bir örnek sunmakta olan yazar, aynı zamanda eseri akademik bir monotonluktan kurtarma gayretindedir.

Eserin ikinci bölümüne (Din ve Stres) din kavramını tanımlayarak başlayan yazar, farklı bakış açılarından din tanımlarını sunmaktadır. Ayrıca bu hususta yazar, din kavramına yaklaşımın nasıl olması gerektiği yönünde önerilerde bulunmaktadır. Tokur, dindarlık kavramını ele alırken dindarlığın tanımının yanı sıra yapısı değinmekte ve yanlış olan genel kabullere bir reddiye kıvamında cevap sunmaktadır. Özelde Din psikolojisi genelde din bilimleri bağlamında son on yılda yeni yeni ilgi gören din-sağlık ilişkisi bakımından bu çalışmaya ilk eserler arasında demek mümkündür. Yazar din-sağlık ilişkisini ele aldığı bölümde dinin ruh ve beden sağlığı üzerine etkilerine değinerek yurt dişında bu hususta yapılan çalışmalar ışığında dinin sağlık üzerindeki etkisinin hangi formlarda nasıl olduğunu izah etmektedir. 
Din-stres ilişkisi başlı̆̆ altında yazar, dinin etki ve işlevi üzerine derinlemesine bilgiler sunmaktadır. Bireyin dindarlı̆̆ının nasıllı̆̆ının dinsağlık ilişkisi bakımından önemine değinen Tokur (s.112), insanların travmatik durumlarla başa çıkabilmek için yaratıcıya yaklaşım şekillerini ortaya koymaya çalışmaktadır, bu izahatı bireyin yaratıcıyla diyaloğu veya yaratıcıya nasıl dua ettiği şekilde yorumlamak mümkündür. İnsanın en zor anlarında gerçek tutumunu ortaya çıkaracağını bireyin içindeki iyi ve kötü yanlarını gün yüzüne çıkaracağını, stresli durumlarda dini referans alan düşünce ve fiiller (dua namaz tefekkür gibi) bireyde oluşabildiğini ifade eden yazar, bu gerekçeler nedeniyle dinin stresle olan ilişkisinden din ve başa çıkmayı incelenmesi gerektiği vurgusunu yapmaktadır. (s.116)

Anlamlandırma sürecine, anlam bulma sürecinde din ve dini inanca değinen yazar, dinin bireyin farklı ihtiyaçlarını karşılayabildiği gibi kişinin başına gelenleri açıklamada ve olanlara bir gerekçe bulmada da dinin küçümsenemez bir rolünün olduğunu ifade etmektedir.

Yazarımız din-stres ilişkisini İslam kaynaklarına göre ele almaya çalışmaktadır. Eser, Türkiye'de konusu bağlamında kaleme alınmış ilk çalışmalardan olması hasebiyle önem arz etmektedir. Alt başlıkları ve referansta bulunduğu ara konularla da birçok çalışmaya 1şık tutacak ve öncülük edecek bir yapiya sahiptir. 